\title{
Work in Progress: Baseline Survey about Community and Identity
}

\section{Abigail M. Clark, Ohio State University}

Abigail Clark is a graduate student at The Ohio State University. Prior to coming to OSU, she earned a B.S. in Mechanical Engineering from Ohio Northern University and spent several years working at Battelle Memorial Institute in Columbus, Ohio. Her research interests include women in engineering. She is currently a Master's student in STEM Education and is planning to pursue a Ph.D. in Engineering Education.

\section{Dr. Rachel Louis Kajfez, Ohio State University}

Dr. Rachel Louis Kajfez is an Assistant Professor in the Department of Engineering Education at The Ohio State University. She earned her B.S. and M.S. degrees in Civil Engineering from Ohio State and earned her Ph.D. in Engineering Education from Virginia Tech. Her research interests focus on the intersection between motivation and identity of undergraduate and graduate students, first-year engineering programs, mixed methods research, and innovative approaches to teaching.

\section{Dr. Mahnas Jean Mohammadi-Aragh, Mississippi State University}

Dr. Jean Mohammadi-Aragh is an assistant professor in the Department of Electrical and Computer Engineering at Mississippi State University. Dr. Mohammadi-Aragh investigates the formation of engineers during their undergraduate degree program, and the use of computing to measure and support that formation. She earned her Ph.D. in Engineering Education from Virginia Tech. In 2013, Dr. Mohammadi-Aragh was honored as a promising new engineering education researcher when she was selected as an ASEE Educational Research and Methods Division Apprentice Faculty. 


\title{
Work in Progress: Baseline Survey about Community and Identity
}

\begin{abstract}
This study examines the communities and identity of First-Year Engineering (FYE) students scoped within the communities of practice framework. A three-part survey is being administered to gather information regarding students' communities of practice and identity. For this Work in Progress paper, we are focusing on the results of the first survey and will present results for all three iterations of the survey in future publications. The questions in the baseline survey focus on confidence in choice of major and the impact of the FYE experience (program or discipline specific course). Demographic information, such as gender, major, and if students are first generation college students was also collected. The baseline survey is being given to engineering students at two large, land grant research-focused universities. At both institutions, the survey is being administered electronically to all FYE students who attended orientation. The results of the survey were analyzed to better understand FYE students' experiences and develop a future protocol and establish a baseline of identity and community development for FYE students. The survey is part of a multi-year project, and this initial understanding will shape future interviews allowing the impact of the FYE experience to be further explored. Ultimately, the larger study seeks to understand the impact various decisions made regarding FYE have on community and identity development as student move through multiple pathways. The baseline survey will guide the development of future aspects of this project while providing insights about FYE students' communities and views of themselves.
\end{abstract}

\section{Introduction}

Over the last several years, there have been calls for changes to engineering education in order to ensure that engineering graduates have the skills to be successful in the workplace (e.g., [1]-[2]). These courses act as a foundation on which build the rest of a student' educational experience and seek to, as recommended by the National Academy of Science, "introduce the "essence" of engineering early in their undergraduate careers" [1, p. 2]. One widely adopted practice from these proposed changes is that of First-Year Engineering (FYE) courses, with nearly $60 \%$ of engineering programs adopting a FYE course by 2013 [3]. Due to each institution's unique history, structures and needs, FYE programs across the country vary with regards to their content[4] and structure[3]. Additionally, there is some variation in timing of FYE courses, as transfer students are often placed in FYE courses in their second or third year. Unfortunately, not much is known about how these choices affect students in the long term.

Identity and community development within engineering often starts with FYE courses. In order to understand the effects of the content, structure and timing on student development into engineering professionals, the framework of communities of practice [5]-[7], connected with situated learning [8], including the key component of identity, is employed. Within this project, identity can be defined as the answer to the question "Who are you?" [9], scoped within the framework of situated learning [8]. This means that the question of "Who are you?" is asked in the context of understanding how students see themselves as engineers and participants in the engineering community. Understanding the factors which affect the development of community 
and identity are especially important in FYE, as these have been tied to recruiting and retaining student in engineering [10], [11].

This Work in Progress paper will describe a baseline survey that FYE students completed as part of a multi-year collaborative research project focused on community and identity. The larger project seeks to answer the question, How do students who are pursuing engineering degrees through pathways that vary with respect to first-year engineering structure, content, and timing describe their experience participating in engineering communities of practice and their emerging engineering identities? This research will investigate the impact of the choices made by institutions, such as structure, content and timing of FYE programs, on students who have taken different routes to and through engineering school. These pathways include traditional engineering students, transfer students and students who are studying at regional campuses. The initial phase of this project is a three-part baseline survey administered to students who have taken FYE this year in order to help us gain insights on students at the beginning of their undergraduate career and to assist in the development of interview protocol for later phases of the project. This paper is focused on the first implementation of the survey. In addition to this implementation of the survey, the second part of the baseline survey will be administered at the end of the first semester, and the final part will be administered at the end of the academic year.

\section{Methods}

The survey was administered electronically and consisted of 20 questions. A link to the survey was sent to students who attended engineering orientation at Institution 1 and Institution 2, two large land-grant research institutions. Institution 1 is located in a rural area in the Southern United States and Institution 2 is located in an urban area of the Midwestern United States. Institution 1 uses a direct matriculation with introduction courses required by all majors, and Institution 2 uses a pre-major with a FYE structure as defined by Chen et al. [3]. At Institution 1, each major offers their own FYE course. At Institution 2, all students take the same course. The survey was sent to approximately $800 \mathrm{FYE}$ students at Institution 1 and approximately $1500 \mathrm{FYE}$ students at Institution 2.

The questions included demographic questions, Likert-like scales, and short answer questions. The demographic questions included questions regarding gender, ethnicity and major of the respondent, as well as if they are first generation students. At Institution 1, the major of the student will allow the student to be tracked to a specific FYE course. The scale questions ask respondents to rate their level of agreement with the statements shown in Table 1. The short answer questions asked the respondent to provide answers to questions such as "Who are you? Please describe yourself in 3-5 sentences", as well as information about activities the respondents participated in during their high school careers, and activities they hoped to participate in while in college. These questions were developed from work by Jones, Paretti, Hein and Knott [12]. The questions measured engineering identity along with other items such as confidence in major and career choice, feeling of belonging in engineering, and engineering expectancy or ability. The construct that each question measures is indicated in the last column of Table 1. 
Table 1: Scale Questions

\begin{tabular}{|c|c|c|}
\hline Question & Statement & Construct \\
\hline 1 & I am confident in my choice of major & Major Choice \\
\hline 2 & $\begin{array}{l}\text { I have sufficient information to make an informed choice about a } \\
\text { specific engineering major }\end{array}$ & Major Choice \\
\hline 3 & I am confident that I want to study engineering & Major Choice \\
\hline 4 & My eventual career will directly relate to engineering & Career Choice \\
\hline 5 & $\begin{array}{l}\text { In the future, I will have a career that requires me to have } \\
\text { engineering skills }\end{array}$ & Career Choice \\
\hline 6 & I plan to continue pursuing an engineering major & Major Choice \\
\hline 7 & $\begin{array}{l}\text { I don't intend to change my major from engineering to a non- } \\
\text { engineering major }\end{array}$ & Major Choice \\
\hline 8 & Being good at engineering is an important part of who I am & Engineering Identity \\
\hline 9 & Doing well on engineering tasks is very important to me & Engineering Identity \\
\hline 10 & Success in engineering school is very valuable to me & Engineering Identity \\
\hline 11 & It matters to me how well I do in engineering school & Engineering Identity \\
\hline 12 & I feel like a real part of my first-year engineering program & $\begin{array}{l}\text { Belonging in } \\
\text { Engineering }\end{array}$ \\
\hline 13 & $\begin{array}{l}\text { Sometimes I feel as if I don't belong in my first-year engineering } \\
\text { program }\end{array}$ & $\begin{array}{l}\text { Belonging in } \\
\text { Engineering }\end{array}$ \\
\hline 14 & People in my first-year engineering program are friendly to me & $\begin{array}{l}\text { Belonging in } \\
\text { Engineering }\end{array}$ \\
\hline 15 & $\begin{array}{l}\text { I am treated with as much respect as other students in my first- } \\
\text { year engineering program }\end{array}$ & $\begin{array}{l}\text { Belonging in } \\
\text { Engineering }\end{array}$ \\
\hline 16 & $\begin{array}{l}\text { I feel very different from most other students in my first-year } \\
\text { engineering program }\end{array}$ & $\begin{array}{l}\text { Belonging in } \\
\text { Engineering }\end{array}$ \\
\hline 17 & The instructors in my first-year engineering program respect me & $\begin{array}{l}\text { Belonging in } \\
\text { Engineering }\end{array}$ \\
\hline 18 & I wish I were in a major other than engineering & $\begin{array}{l}\text { Belonging in } \\
\text { Engineering }\end{array}$ \\
\hline 19 & I feel proud of belonging in my first-year engineering program. & $\begin{array}{l}\text { Belonging in } \\
\text { Engineering }\end{array}$ \\
\hline 20 & $\begin{array}{l}\text { Compared to other engineering students, I expect to do well in } \\
\text { my engineering-related courses this year }\end{array}$ & $\begin{array}{l}\text { Engineering } \\
\text { Expectancy or Ability }\end{array}$ \\
\hline 21 & $\begin{array}{l}\text { I think that I will do well in my engineering-related courses this } \\
\text { year. }\end{array}$ & $\begin{array}{l}\text { Engineering } \\
\text { Expectancy or Ability }\end{array}$ \\
\hline 22 & I am good at math, science and engineering & $\begin{array}{l}\text { Engineering } \\
\text { Expectancy or Ability }\end{array}$ \\
\hline 23 & $\begin{array}{l}\text { Compared to other engineering students, I have high engineering- } \\
\text { related abilities }\end{array}$ & $\begin{array}{l}\text { Engineering } \\
\text { Expectancy or Ability }\end{array}$ \\
\hline 24 & $\begin{array}{l}\text { I have been doing well in my engineering-related courses this } \\
\text { year }\end{array}$ & $\begin{array}{l}\text { Engineering } \\
\text { Expectancy or Ability }\end{array}$ \\
\hline
\end{tabular}

\section{Limitations}

The survey had a low response rate, but one that was typical of this type of research. Of approximately 2300 surveys distributed, there were 422 responses received, or a response rate of $18.3 \%$. Institution 1 had a slightly lower response rate, 294 responses or $15.5 \%$, than Institution 
2 , which had 124 responses or $19.9 \%$. However, of these 422 responses, only 300 were complete. This leaves a response rate of $13 \%$ for the useable surveys. The low response rate may create a non-response bias and limit the ability of these results to be broadly applied. These responses are collected from one cohort of FYE students at two institutions, so this may also limit the generalizability of the results. Additionally, by gathering the list of students for the initial survey distribution from the list of students who attended orientation, it is possible that students who are currently enrolled in FYE but for some reason did not attend orientation were not included in the initial survey distribution and are therefore not represented. While there are limitation, since this is a baseline, we believe it still provides valuable results and insights for future phases of this work.

\section{Results}

As stated above, 300 responses were deemed complete and used for this analysis. A complete response was one where the respondent answered all of the closed ended questions. Most of the incomplete responses failed to complete a portion of, or all of, the closed-ended questions. There were 113 complete responses from Institution 1, and 187 complete responses from Institution 2. The demographics of the respondents are shown in Table 2.

Table 2: Demographics of the Respondents

\begin{tabular}{|l|l|l|}
\hline Demographics & Institution 1 & Institution 2 \\
\hline Male & $61 \%$ & $66 \%$ \\
\hline Female & $39 \%$ & $33 \%$ \\
\hline Primary Race & White (81\%) & White (73\%) \\
\hline First Generation Students & $18 \%$ & $14 \%$ \\
\hline Top 3 Majors & Chemical Engineering (17\%) & $\begin{array}{l}\text { Computer Science and } \\
\text { Engineering (23\%) }\end{array}$ \\
\cline { 2 - 3 } & Biological Engineering (17\%) & $\begin{array}{l}\text { Mechanical Engineering } \\
(16 \%)\end{array}$ \\
\cline { 2 - 3 } & $\begin{array}{l}\text { Mechanical Engineering } \\
(16 \%)\end{array}$ & $\begin{array}{l}\text { Biomedical Engineering } \\
(14 \%)\end{array}$ \\
\hline
\end{tabular}

Using the responses gathered, an average response was found. This was done by giving a response of "Strongly Agree" a score of 6, a response of "Agree" a score of 5, a response of "Somewhat Agree" a score of 4, a response of "Somewhat Disagree" a score of 3, a response of "Disagree" a score of 2, and a response of "Strongly Disagree" a score of 1. Additionally, questions 13,16 and 18 were reverse coded. These 3 questions were originally asked in the negative, for example question 18 states "I wish I were in a major other than engineering". Strongly agreeing with one of these questions would indicate a low level of the construct the question was trying to measure. Therefore, in order to ensure that a high average score indicated higher levels of the measured concepts, the responses for the identified questions were "flipped", i.e. "Strongly Agree" became "Strongly Disagree", "Agree" became "Disagree, and so on.

In order to understand first-year students' engineering identity, confidence in major and career choice, feeling of belonging in engineering and engineering expectancy or ability at the 
beginning of their FYE experiences, and how they may differ by institution or gender, the results were examined using independent-samples $t$-tests. A $t$-test assumes that the survey responses in the population would be normal, however, at relatively large sample sizes (30 or greater), a nonnormal population would have little effect on the results [13]. A two-tailed independent-samples $t$-test on each question was conducted to determine if there is a difference between Institution 1 and Institution 2 at $\alpha=0.05$. Several significant differences were found. Of the questions relating to major choice, students from Institution 1 reported higher levels of agreement with the given statements than students from Institution 2 for question $1(p=0.023)$, question $3(p<0.001)$, and question $7(p=0.004)$. Of the questions related to engineering identity, it was found that Institution 1 had higher responses than Institution 2 for question $8(p=0.02)$ and question $9(p=$ $0.01)$. Of the questions relating to engineering belonging, it was found that Institution $2 \mathrm{had}$ a higher average response than Institution 1 for question $16(p=0.04)$ and that Institution 1 had a higher average response than Institution 2 for question $18(p=0.02)$. It should be noted that the responses to both question 16 and 18 were reverse coded. See Table 3 for more details. In the questions regarding engineering expectancy or ability, only question 21 was found to have a statistically significant different between Institution 1 and Institution 2 . It was found that Institution 1 had a higher average response than Institution $2(p=0.04)$.

Table 3: Comparing mean values between Institution 1 and Institution 2

\begin{tabular}{|l|l|l|l|l|l|l|l|}
\hline Question & $\begin{array}{l}\text { Institution 1 } \\
M(S D)\end{array}$ & $\begin{array}{l}\text { Institution 2 } \\
M(S D)\end{array}$ & Mean Difference & $t$ & $d f$ & $p$ & $d$ \\
\hline 1 & $3.62(1.81)$ & $3.15(1.55)$ & 0.47 & 2.30 & 207.63 & .02 & 0.28 \\
\hline 3 & $4.71(1.79)$ & $3.80(1.79)$ & 0.91 & 4.28 & 298 & $<.001$ & 0.51 \\
\hline 7 & $4.57(1.81)$ & $3.94(1.82)$ & 0.63 & 2.89 & 298 & .004 & 0.35 \\
\hline 8 & $3.81(1.60)$ & $3.39(1.46)$ & 0.42 & 2.35 & 298 & .02 & 0.27 \\
\hline 9 & $4.19(1.94)$ & $3.61(1.82)$ & 0.57 & 2.53 & 224.68 & .01 & 0.31 \\
\hline 16 & $4.18(1.18)$ & $4.46(1.14)$ & -0.28 & -2.06 & 298 & .04 & 0.24 \\
\hline 18 & $5.26(1.00)$ & $4.93(1.21)$ & 0.33 & 2.45 & 298 & .02 & 0.30 \\
\hline 21 & $3.83(1.89)$ & $3.38(1.60)$ & 0.45 & 2.13 & 207.47 & .04 & 0.26 \\
\hline
\end{tabular}

There was no significant difference between the institutions in the questions regarding career choice. Figure 1 shows the average responses for the questions with significant differences by institution. 


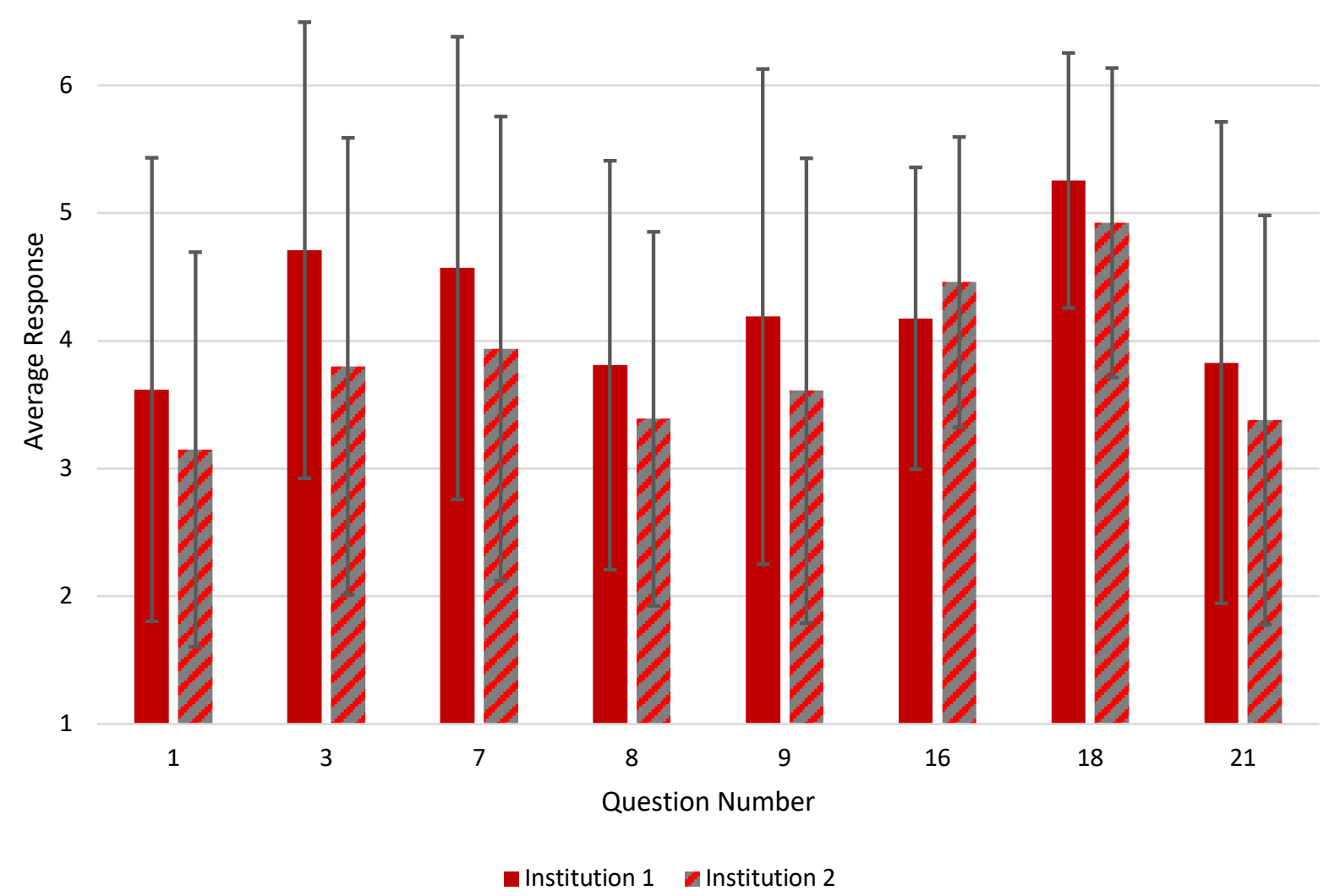

Figure 1: Average response per question by institution on a scale of one to six, questions with significant difference, $\alpha=0.05$

The survey responses were also analyzed to determine if there was a difference between the responses of male and female students. Again, a two-tailed independent-samples $t$-test was conducted and a significance level of $\alpha=0.05$ was chosen. Gender was indicated by respondents, and those who did not indicate a gender were excluded from this analysis. Several questions were found to have statistical significance. Question 1, which relates to engineering identity, found that female students had lower average responses than male students $(p=.004)$. Two questions relating to belonging to engineering were found to have significantly different responses. It was found that female students had a lower average response than male students on both question $13(p=.02)$ and question $15(p=.049)$. It should be noted that the responses to question 13 were reverse coded. When examining the questions related to engineering expectancy or ability, it was found that female students had lower responses than male student for question $22(p=.02)$ and question $23(p=.03)$. See Table 4 for more details. 
Table 4: Comparing mean values between female and male students

\begin{tabular}{|l|l|l|l|l|l|l|l|}
\hline Question & $\begin{array}{l}\text { Female } \\
M(S D)\end{array}$ & $\begin{array}{l}\text { Male } \\
M(S D)\end{array}$ & Mean Difference & $t$ & $d f$ & $p$ & $d$ \\
\hline 1 & $2.98(1.49)$ & $3.55(1.74)$ & -0.57 & -2.88 & 228.05 & 0.004 & 0.35 \\
\hline 13 & $4.14(1.13)$ & $4.50(1.22)$ & -0.35 & -2.37 & 273 & 0.02 & 0.30 \\
\hline 15 & $3.56(1.83)$ & $4.03(1.93)$ & -0.47 & -1.98 & 273 & 0.049 & 0.25 \\
\hline 22 & $3.35(1.69)$ & $3.89(1.89)$ & -0.55 & -2.46 & 219.80 & 0.02 & 0.30 \\
\hline 23 & $3.23(1.23)$ & $3.62(1.52)$ & -0.38 & -2.26 & 237.90 & 0.03 & 0.28 \\
\hline
\end{tabular}

No significant differences were found between male and female students in the areas of major or career choice. Figure 2 shows the average response for the questions with statistically significant differences by gender.

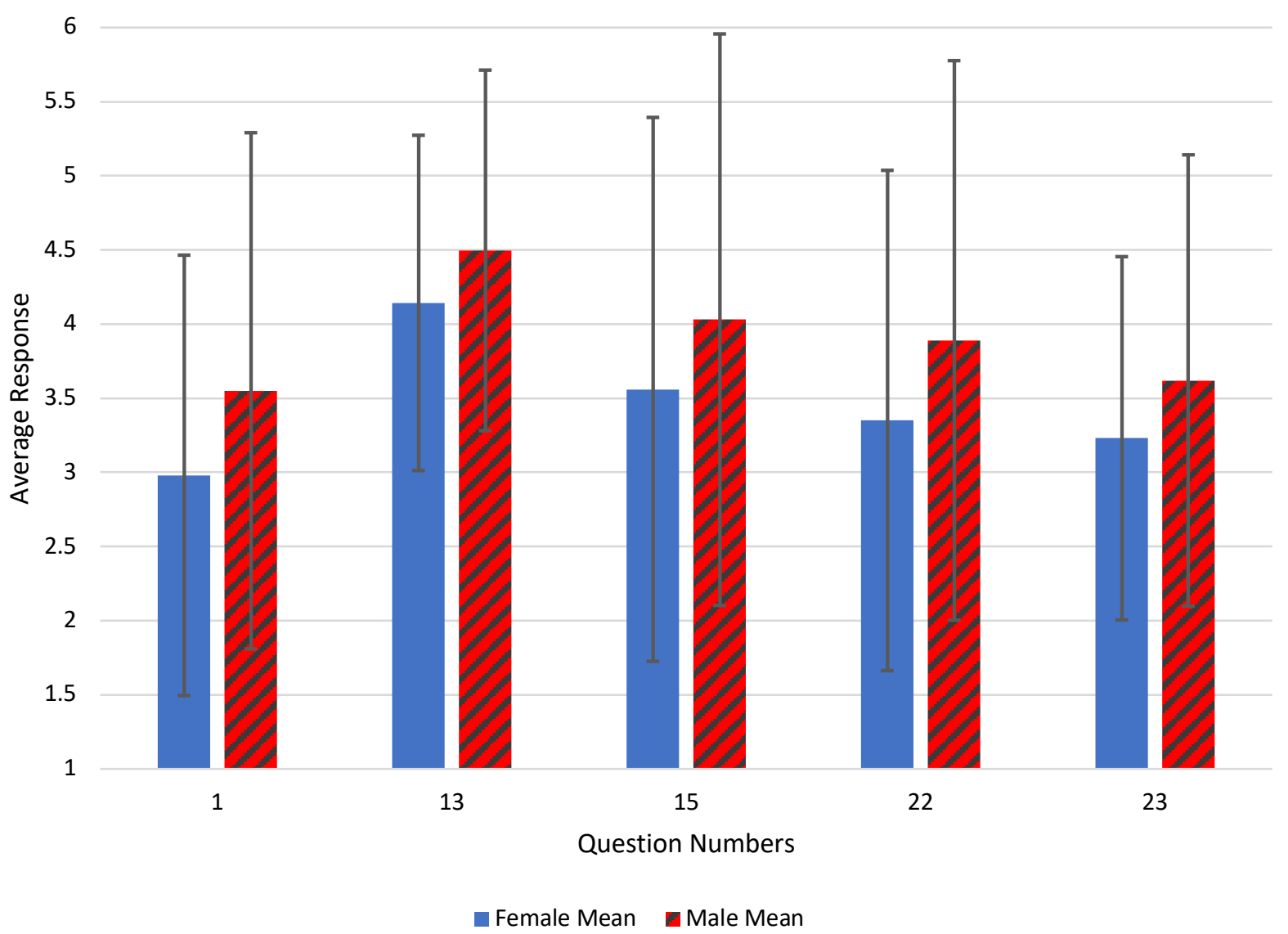

Figure 2: Average response per question by gender on a scale of one to six, questions with significant differences, $\alpha=0.05$

Finally, the survey responses were analyzed to determine if the responses differed by major. The top 4 majors, which represents 180 of our 300 respondents, were analyzed. These majors were computer science and engineering, which was defined at Institution 1 as the Computer Science, Computer Engineering and Software Engineering students; Mechanical Engineering; Biological and Biomedical Engineering; and Chemical Engineering. First, a one-way ANOVA was 
conducted. An ANOVA is used to compare the variances between more than two groups [13]. Most questions were found to have non-significant variation between majors. However, two questions showed significance after the ANOVA test. The results for these questions are shown in Table 5

Table 5: ANOVA results for significant questions, by major

\begin{tabular}{|l|l|r|r|r|r|r|}
\hline & & Sum of Squares & df & Mean Square & $F$ & $p$ \\
\hline \multirow{4}{*}{ Q11 } & Between Groups & 29.60 & 3 & 9.87 & 2.971 & .033 \\
\cline { 2 - 7 } & Within Groups & 584.40 & 176 & 3.32 & & \\
\cline { 2 - 8 } & Total & 614 & 179 & & & \\
\hline \multirow{2}{*}{ Q19 } & Between Groups & 30.13 & 3 & 10.04 & 3.199 & .025 \\
\cline { 2 - 7 } & Within Groups & 552.59 & 176 & 3.14 & & \\
\cline { 2 - 7 } & Total & 582.73 & 179 & & & \\
\hline
\end{tabular}

The response to question 11 was found to differ significantly according to major, $F(3,176)=$ $2.971, p=.033, \eta=.05$, and question 19 was also found to differ significantly by major $F(3,176)$ $=3.199, p=.025, \eta=.05$. A post-hoc Bonferroni test was conducted, however, none of the differences were found to be statistically significant at this stage.

\section{Discussion}

The results from the initial baseline survey indicate that the students who have enrolled in a direct matriculation with introduction course (Institution 1) initially may have higher levels of confidence in career choice, engineering identity and engineering expectancy and ability. These students also generally show a slightly higher level of a sense of belonging in engineering in some aspects; however, this is the construct where students who participated in a pre-major with FYE structure (Institution 2) showed a slightly higher level in other aspects. The survey results indicate that female students initially show a lower level some aspects of engineering identity, belonging in engineering, and engineering expectancy and ability. These areas will be investigated especially carefully within subsequent implementations of the survey and will also influence additional phases of work.

\section{Future work}

The results of this survey will help inform future phases of the project. After the baseline survey, the first full phase of the study will be interviews with some students who took FYE the previous year. Students will be recruited for these interviews using a survey similar to the baseline survey. These students will be interviewed again in the second phase of the project, two years removed from their FYE experience, and again three years removed from their FYE experience. The final phase of the project is to conduct interviews and focus groups with TAs, faculty, and administrators.

This survey of freshman students enrolled in different FYE structures will provide insight into how the structure of FYE programs impact student community and identity development. 
Understanding how these structures affect student community and identity development can allow FYE programs to make evidenced-based changes in order to support community and identity development in their students.

\section{Acknowledgements}

This material is based upon work supported by the National Science Foundation under Grant Nos. 1664264 and 1664266. Any opinions, findings, and conclusions or recommendations expressed in this material are those of the author(s) and do not necessarily reflect the views of the National Science Foundation.

\section{References}

[1] N. A. of Engineering., "Educating the engineer of 2020 : adapting engineering education to the new century." National Academies Press, Washington, D.C., 2005.

[2] N. Nielsen, N. R. C. (U.S.)., and P. C. on E. on S. I. in U. S. Education., "Promising practices in undergraduate science, technology, engineering, and mathematics education : summary of two workshops." National Academies Press, Washington, D.C., 2011.

[3] X. Chen, C. E. Brawner, M. W. Ohland, and M. K. Orr, "A Taxonomy of Engineering Matriculation Practices," 120th ASEE Annu. Conf. Expo., 2013.

[4] K. J. Reid, D. Reeping, T. Hertenstein, G. Fennel, and E. Spingola, "Development of a Classification Scheme for ' Introduction to Engineering' Courses," Found. Eng. Conf., 2013.

[5] E. Wenger, "Communities of Practice and Social Learning Systems," Organization, vol. 7, no. 2, pp. 225-246, 2000.

[6] E. Wenger, Communities of practice : learning, meaning, and identity. Cambridge, U.K.; New York, N.Y.: Cambridge University Press, 1998.

[7] E. Wenger, "Communities of Practice: Learning as a social system," Syst. Thinker, vol. 9, no. 5, pp. 2-3, 1998.

[8] J. Lave and E. Wenger, Situated learning : legitimate peripheral participation. Cambridge [England]; New York: Cambridge University Press, 1991.

[9] V. L. Vignoles, S. J. Schwartz, and K. Luyckx, "Introduction: Toward an integrated view of identity," in Handbook of Identity Theory and Research, vol. 1, New York: Springer, 2011, pp. 1-27.

[10] T. Beam, O. Pierrakos, J. Constantz, A. Johri, and R. Anderson, "Preliminary Findings on Freshmen Engineering Students ' Professional Identity : Implications for Recruitment and Reten," Am. Soc. Eng. Educ., 2009.

[11] B. D. Jones, J. W. Osborne, M. C. Paretti, and H. M. Matusovich, "Relationships among students' perceptions of a first-year engineering design course and their engineering identification, motivational beliefs, course effort, and academic outcomes," Int. J. Eng. Educ., vol. 30, no. 6, pp. 1340-1356, 2014.

[12] B. D. Jones, M. C. Paretti, S. F. Hein, and T. W. Knott, "An Analysis of Motivation Constructs with First-Year Engineering Students: Relationships Among Expectancies, Values, Achievement, and Career Plans," J. Eng. Educ., vol. 99, no. 4, pp. 319-336, 2010.

[13] F. J. Gravetter and L. B. Wallnau, Statistics for the Behavioral Sciences, 10th ed. Boston: Cengage Learning, 2017. 